\title{
Analisis Biblika Baptisan Roh Kudus Dan Penuh Dengan Roh Kudus
}

\section{Asih Rachmani Endang Sumiwi ${ }^{1}{ }^{*}$}

1) Dosen Sekolah Tinggi Theologia Berita Hidup

*) Penulis korespondensi: asihres@gmail.com

Received: 5 March 2018 / Revised: 11 April 2018 / Accepted: 20 May 2018

\begin{abstract}
Abstrak
Baptisan Roh Kudus dan penuh dengan Roh Kudus adalah istilah umum di kalangan Gereja-gereja Pentakosta dan Karismatik. Namun demikian kedua hal ini kadang-kadang dipertanyakan di kalangan gereja-gereja arus utama, khususnya sehubungan dengan tanda-tanda lahiriah yang menyertai peristiwa baptisan Roh Kudus.

Untuk menjawab pertanyaan ini perlu dilakukan analisis biblikal. Analisis biblikal ini meliputi definisi dalam bahasa aslinya, yaitu bahasa Yunani, menginventarisasi bagaimana hal-hal tersebut terjadi dan dituliskan di dalam Alkitab, lalu secara induktif ditarik kesimpulan mengenai baptisan Roh Kudus dan penuh dengan Roh Kudus.
\end{abstract}

Baptisan Roh Kudus memiliki dua pengertian: yang pertama, seseorang dibaptis oleh Roh Kudus ke dalam tubuh Kristus sehingga menjadi bagian dari tubuh Kristus (1 Kor. 12:12-13); yang kedua, sesorang dibaptis oleh Tuhan Yesus ke dalam Roh Kudus sehingga ia berada dalam penguasaan Roh Kudus (Mrk 1:8).

Penuh dengan Roh Kudus adalah keadaan di mana Roh Kudus menguasai atau mengendalikan seluruh segi kehidupan orang percaya tersebut sehingga apa yang dilakukan seperti apa yang Roh Kudus mau.

Kata-kata kunci: baptisan Roh, kepenuhan Roh, Roh Kudus, glossolalia, bahasa roh 
The baptism of the Holy Spirit and filled with the Holy Spirit is a general term among Pentecostal and Charismatic Churches. However, these two things are sometimes questioned among mainline churches, especially with regard to the outward signs that accompany the event of the baptism of the Holy Spirit.

To answer this question a biblical analysis is needed. This biblical analysis includes definitions in the original Greek, inventorying how they happened and written in the Bible, and then inductively drawn the conclusion of the baptism of the Holy Spirit and filled with the Holy Spirit.

The baptism of the Holy Spirit has two meanings: first, a person is baptized by the Holy Spirit into the body of Christ to become part of the body of Christ (1 Cor 12: 12-13); the second, a person baptized by the Lord Jesus into the Holy Spirit so that he is under the control of the Holy Spirit (Mk 1:8).

Full of the Holy Spirit is a state in which the Holy Spirit overwhelms or controls all aspects of the believer's life so that what he does as the Holy Spirit des.

Key Words: Baptism of The Holy Spirit, Holy Spirit, Glossolalia

\section{Pendahuluan}

Baptisan Roh Kudus dan penuh dengan Roh Kudus merupakan suatu pengalaman rohani yang sering diperbincangkan di kalangan orang percaya. Ada yang menganggapnya satu kejadian yang sama dan ada pula yang menganggap suatu kejadian yang berbeda. Bahkan ada yang menerimanya namun ada pula yang menolaknya. Hal tersebut mendorong penulis untuk mencaritahu apa yang sebenarnya dikatakan Alkitab mengenai Baptisan Roh Kudus dan Kepenuhan Roh Kudus.

Yohanes 14:16-18, "Aku akan minta kepada Bapa, dan Ia akan memberikan kepadamu seorang Penolong yang lain, supaya Ia menyertai kamu selama-lamanya, yaitu Roh Kebenaran. Dunia tidak dapat menerima Dia, sebab dunia tidak melihat Dia dan tidak mengenal Dia. Tetapi kamu mengenal Dia, sebab Ia menyertai kamu dan akan diam di dalam kamu. Aku tidak akan meninggalkan kamu sebagai yatim piatu. Aku datang kembali kepadamu." Dalam ayat ini Tuhan menjanjikan Roh Kudus yang akan menyertai hidup orang 
percaya dan tidak ditinggalkan yatim piatu. Setelah Dia ke sorga, Roh Kudus turun memenuhi para murid dan orang percaya. Mereka mengalami kuasa Roh Kudus dan hidup dalam pimpinan-Nya sehingga memiliki kuasa yang besar untuk menjadipengikut Kristus yang setia dan memberitakan karya keselamatan bagi banyak orang.

\section{Baptisan Roh Kudus}

\section{Pengertian Baptisan}

Baptisan berasal dari kata Baptisma, merupakan tindakan dari pencucian atau memasukkan kedalam air, sebagai simbol penyucian, pembersihan. Simbolisme sering dilakukan oleh orang-orang di Perjanjian Lama. Ini adalah suatu tanda setiap orang yang masuk dalam komunitas baru. Baptisan juga memiliki pengertian sebagai tanda pertobatan seseorang, dari kehidupan yang lama untuk mendapatkan kehidupan baru. Baptisan ini digunakan oleh Yohanes ketika menyambut kedatangan Tuhan Yesus.

Baptisan biasanya disebut sebagai inagurasi dimana seseorang mempercayai tentang keselamatan di dalam Yesus. Bukan masalah baptisannya tetapi proses pekerjaan Roh kudus yang merupakan hal yang penting. Sama seperti orang wisuda bukan wisudanya yang membuat seseorang lulus kuliah, tetapi proses belajar dan ketekunan seseorang melewati studi itu. Sebuah inagurasi penting untuk menjadi pengingat tetapi bukan itu menentukan segalanya. Baptisan adalah simbol bagaimana dia diselamatkan.

Sebelum meneruskan fakta lainnya, ada baiknya melihat arti dari "kepenuhan", "penuh dengan", atau "dipenuhi oleh" Roh. Secara umum dipenuhi oleh Roh berarti dikuasai dan didominasi oleh hadirnya Pribadi dan kuasa Roh dalam diri orang percaya. Bila dibandingkan dengan konteks Efesus 5:18, dipenuhi Roh dapat berarti "berada di bawah pengaruh Roh" (bandingkan dengan "mabuk anggur" yang artinya "di bawah pengaruh anggur"), dalam pengertian yang kontinu dan (bisa) berulang kali (perhatikan bentuk present tense). Dalam satu kalimat dapat dikatakan bahwa pemenuhan Roh merupakan suatu tuntutan yang seharusnya ada di dalam diri orang Kristen secara terus-menerus dan nyata terlihat dari luar oleh orang lain.

Dipenuhi Roh berlainan dengan baptisan Roh. Baptisan Roh berlangsung atau terjadi hanya satu kali yaitu ketika seseorang 
menerima Kristus sebagai Juruselamat. Ia diyakinkan oleh Roh tentang keselamatan, dilahirbarukan, dimeteraikan, dan dibaptis oleh Roh (bnd. 1 Kor 12:13). Barulah setelah itu orang tersebut bisa atau tidak dipenuhi Roh tergantung kepada kadar imannya serta penyerahannya di hadapan Tuhan.

Maka jelaslah bahwa seorang Kristen yang tidak dipenuhi Roh adalah seorang Kristen yang "kering". Hal ini akan terlihat dalam seringnya ia gagal dalam menghadapi pencobaan, tidak tampak buah Roh, tidak mampu dan tidak mau bersaksi, tidak ada kemajuan dalam pelayanan, tidak ada kuasa, dan sebagainya.

Tetapi sebaliknya, ada satu catatan yang menarik yang dapat dilihat di dalam Alkitab tentang orang yang dipenuhi Roh; yaitu bahwa orang yang dipenuhi Roh tidak pernah mengatakan bahwa dirinya dipenuhi Roh. Orang lain yang melihat dan menyaksikan bahwa ia dipenuhi Roh. Mereka menyaksikan ada buah Roh dan buah pelayanan di dalam kehidupannya. Sebab itu kepenuhan Roh adalah suatu keharusan, sesuatu yang normal bagi kehidupan setiap orang Kristen. Kepenuhan Roh tidak boleh dianggap sebagai sesuatu keanehan, kelainan, sesuatu yang luar biasa, dan hanya sedikit orang saja yang dipenuhi. ${ }^{1}$ Baptisan Roh Kudus diperuntukkan bagi setiap orang percaya di dalam setiap generasi.

\section{Baptisan Roh Kudus}

Baptisan Roh Kudus secara langsung disebut dalam Alkitab 7 kali di Perjanjian Baru. Pemunculan istilah ini yang pertama dalam Mat. 3:11 ("Aku membaptis kamu dengan air sebagai tanda pertobatan, tetapi Ia yang datang kemudian dari padaku lebih berkuasa dari padaku dan aku tidak layak melepaskan kasut-Nya. Ia akan membaptiskan kamu dengan Roh Kudus dan dengan api") dan sama persis digunakan dalam Markus 1:8; Lukas 3:16 dan Yohanes 1:31-33. Ke empat ayat itu semua disebutkan oleh Yohanes Pembaptis. Yesus juga mengungkapkan mengenai hal ini dalam Kisah Para Rasul 1:45. Dikatakan demikian, "Pada suatu hari ketika Ia makan bersamasama dengan mereka, Ia melarang mereka meninggalkan Yerusalem, dan menyuruh mereka tinggal di situ menantikan janji Bapa, yang -

${ }^{1}$ Billy Graham mengatakan: "It is intended for all, needed by all, and available 
demikian kata-Nya -- "telah kamu dengar dari pada-Ku.Sebab Yohanes membaptis dengan air, tetapi tidak lama lagi kamu akan dibaptis dengan Roh Kudus". Pengungkapan ini dilakukan Yesus pertama kali dan hanya sekali selama hidup-Nya. Selanjutnya istilah ini muncul dalam Kisah Para Rasul 11:15-17 ("Dan ketika aku mulai berbicara, turunlah Roh Kudus ke atas mereka, sama seperti dahulu ke atas kita. Maka teringatlah aku akan perkataan Tuhan: Yohanes membaptis dengan air, tetapi kamu akan dibaptis dengan Roh Kudus. Jadi jika Allah memberikan karunia-Nya kepada mereka sama seperti kepada kita pada waktu kita mulai percaya kepada Yesus Kristus, bagaimanakah mungkin aku mencegah Dia?"). Di sini pemunculannya bukan dalam rangka janji Tuhan atau perintah untuk diterima tetapi justru mengingatkan kembali apa yang telah dijanjikan Tuhan dan yang telah terjadi pada hari Pentakosta yang telah berlalu. Petrus tidak sedang menganjurkan gereja lain untuk menerima baptisan Roh Kudus, tetapi membicarakan apa yang telah terjadi dalam sejarah, yang tidak pernah terulang kembali. Terakhir kali istilah baptisan Roh Kudus muncul di 1 Korintus 12:13, "Sebab dalam satu Roh kita semua, baik orang Yahudi, maupun orang Yunani, baik budak, maupun orang merdeka, telah dibaptis menjadi satu tubuh dan kita semua diberi minum dari satu Roh."2

Di sini juga Alkitab memberikan definisi atau menjelaskan makna baptisan Roh Kudus yang memberi pengalaman yang lebih luas bagi semua orang percaya, yaitu mempersatukan semua orang percaya menjadi satu tubuh.

Baptisan yang dilakukan oleh Yesus Kristus, karena Kristus mengutus Roh Kudus sebagai penolong bagi orang percaya untuk terus bertahan. Baptisan Roh Kudus adalah suatu kata yang mana penulis PB gunakan untuk berbicara tentang datangnya ' $a$ new convenant power of Holy Spirit'.

Perbedaan baptisan air dan baptisan Roh Kudus adalah bahwa baptisan dengan air adalah sebagai pernyataan iman (segi manusia). Orang Kristen mengimani bahwa pada saat dibaptis mereka menjadi satu bagian keluarga kerajaan Allah dan menjadi pribadi yang diselamatkan Tuhan. Ini adalah bukti bahwa mereka sudah di dalam Kristus, sedangkan baptisan dengan Roh adalah sebagai penyataan

\footnotetext{
${ }^{2}$ Brian J. Bailey, Roh Kudus Sang Penghibur, Nafiri Gabriel, Jakarta, 1997,
} hal 121 
anugerah Allah. Stott selanjutnya memperjelas bahwa bahasa baptisan Roh adalah sebuah pengalaman kristiani yang mula pertama sekali, yang memasukkan 'orangnya' ke dalam persekutuan dengan Kristus. $^{3}$

Berbeda dengan baptisan Roh yang diberikan sekali untuk selamanya dan tidak dapat hilang, Stott berujar bahwa kepenuhan Roh ialah karunia yang perlu dijadikan milik terus-menerus dan bertambah-tambah, serta bagaimana pun juga perlu dipertahankan. Ia kemudian menjelaskan ciri-ciri kepenuhan Roh (yang hanya bisa terjadi dengan datang kepada Kristus), yakni ada kerinduan bersekutu dalam wujud berbakti bersama, ada dorongan untuk bernyanyi dan bersorak bagi Tuhan, ada sikap yang senantiasa mengucap syukur atas segala sesuatu, dan ada penundukan diri dengan rendah hati.

Setelah membahas aspek perintah terus-menerus dari kepenuhan Roh dan bahaya kehidupan Kristen yang statis, Stott mengingatkan agar orang Kristen berhati-hati terhadap pengalamanpengalaman khusus dari beberapa orang. Meski ada beberapa pengalaman yang mungkin otentik, tetapi ia menegaskan bahwa pengalaman tersebut berbeda-beda (sehingga tidak bisa menjadi patokan), bersifat sekunder dan tidak lengkap.

Bagaimana Mengetahui bahwa Seseorang Sudah Dibaptis Roh Kudus?

Gerakan Roh Kudus tidak dapat dilihat tetapi yang dihasilkan dari gerakan Roh Kudus dapat dilihat. Hal ini diajarkan Yesus kepada Nikodemus dalam Yohanes 3:8, "Angin bertiup kemana ia mau, dan engkau tidak tahu dari mana ia dating atau kemana ia pergi. Demikianlah halnya dengan tiap-tiap orang yang lahir dari Roh." Baptisan sebagai sarana penting dalam menghayati keselamatan yang disediakan di dalam Kristus.

\section{Prinsip Alkitab Tentang Baptisan Roh Kudus}

Ada dua pengertian yang ditulis Alkitab mengenai baptisan Roh Kudus:

${ }^{3}$ John R.W. Stott, Baptisan dan Kepenuhan: Peranan Dan Karya Roh Kudus Masa Kini, hal 43 
- Baptisan Roh Kudus dengan pengertian seseorang dibaptis oleh Roh Kudus ke dalam tubuh Kristus (1 Kor 12:12-13).

- Baptisan Roh Kudus dengan pengertian sesorang dibaptis oleh Tuhan Yesus ke dalam Roh Kudus (Mrk 1:8).

Orang yang sudah menerima Yesus sebagai Tuhan dan Juruselamat, ia dibaptis Roh Kudus ke dalam tubuh Kritus tetapi hal dibaptis ke dalam Roh Kudus adalah peristiwa khusus yang tidak selalu dialami oleh orang percaya.

Ada empat fakta turunnya Roh Kudus, yaitu: dalam Kis 2:38 (di Yerusalem dan disertai bahasa roh), Kis 8:14-17 (di Samaria dan tidak disertai bahasa roh), Kis 10:44 (kepada Kornelius dan disertai bahasa roh), Kis 19:1-6 (di Efesus dan disertai bahasa roh dan bernubuat).

"Di dalam kelahiran baru Roh Kuduslah yang bekerja aktif, sarananya adalah darah penebusan, hasilnya kelahiran baru; tetapi di dalam baptisan Roh, Kristuslah yang bekerja aktif, sarananya adalah Roh, hasilnya adalah mendapatkan kuasa (dari atas)" 4

Jadi, kepenuhan Roh adalah akibat dari baptisan Roh (Kis 2:4). Tuhan Yesus membaptis dengan Roh Kudus, kepenuhan Roh Kudus adalah akibat yang diterima. Kepenuhan Roh yang diterima perlu terus menerus dijaga dan dipertahankan. Jika orang percaya hidup dalam ketaatan terhadap Roh Kudus maka akan mengalami kepenuhan Roh Kudus. Sepanjang kisah dalam alkitab tidak ada seorang rasul yang mengatakan 'Aku kepenuhan Roh Kudus'. Tetapi hal itu menjadi peryataan dari orang yang memandang mereka bahwa mereka dipenuhi oleh Roh Kudus. Kepenuhan Roh Kudus adalah keadaan yang seharusnya dijaga dan dipertahankan. Dalam Efesus 5:18-19 dikatakan, "Dan janganlah kamu mabuk oleh anggur, karena anggur menimbulkan hawa nafsu, tetapi hendaklah kamu penuh dengan Roh, dan berkata-katalah seorang kepada yang lain dalam mazmur, kidung puji-pujian dan nyanyian rohani. Bernyanyi dan bersoraklah bagi Tuhan dengan segenap hati”. Ini adalah hidup yang dipenuhi oleh Roh.

\section{Ciri-Ciri Orang Dipenuhi Roh Kudus}

- Taat kepada Roh.

\footnotetext{
${ }^{4}$ Bruner, A Theological of The Holly Spirit, hal 60
} 
- Hidup kudus

- Menjunjung tinggi Firman Tuhan (Yohanes 14:26)

- Mengabarkan Injil (Kisah Para Rasul 1:8)

- Berani dipimpin Roh Kudus untuk menjalankan kehendak Allah (Kisah Para Rasul 16:9-40)

- Menghasilkan buah Roh (Kisah Para Rasul 13:52, Efesus 5:18)

Baptisan Roh Kudus terjadi satu kali di dalam kehidupan orang percaya dan untuk selama-lamanya. Tidak ada pengulangan. Sedangkan kepenuhan Roh Kudus bisa terjadi berulang kali dalam perjalanan kehidupan orang percaya. Baptisan Roh Kudus adalah pengalaman yang pasti tanpa diragukan, dialami oleh setiap orang percaya ketika dia menerima Kristus sebagai Tuhan dan juruselamatnya. Baptisan Roh Kudus bukan pengalaman kedua yang baru akan dialami setelah orang percaya tersebut menerima pelayanan khusus, misalnya penumpangan tangan, tetapi hal yang langsung dialaminya sama ketika ia menerima Kristus sebagai Tuhan dan juruselamatnya. Baptisan Roh Kudus adalah kenyataan atau fakta seseorang menerima Kristus dan dengan demikian menjadi alat (means) Tuhan melalui orang tersebut. Dipersatukan ke dalam Baptisan Roh Kudus terjadi satu kali di dalam kehidupan orang Kristen untuk selama-lamanya (tidak ada pengulangan), sedangkan kepenuhan Roh Kudus terjadi berulang kali di dalam perjalanan kehidupan kekristenan. Di dalam baptisan Roh Kudus, Roh Kudus masuk di dalam hati orang percaya, sedangkan di dalam kepenuhan Roh Kudus, Roh Kudus mencerahkan dan memimpin orang percaya menuju kepada kesempurnaan hidup seperti Kristus (Roh Kudus tidak masuk untuk kedua kalinya di dalam hati orang percaya).

Perisiwa dalam Alkitab yang menunjukkan perbedaan antara kelahiran baru dan baptisan Roh Kudus, antara lain: Pertama, para murid Kristus. Mereka telah mengaku Yesus adalah Kristus, Anak Allah yang hidup (Mat 16:16, Yoh 6:68-69). Yesus mengatakan bahwa nama mereka tertulis di Surga (Luk 10:20). Setelah kebangkitan, Yesus mengembusi para muridnya dan berkata, Terimalah Roh Kudus (Yoh 20:21), namun mereka tetap diperintahkan untuk menantikan janji Bapa yakni diperlengkapi dengan kekuasaan dari tempat tinggi (Luk 24:49), yang kemudian digenapkan pada hari Pentakosta dengan pencurahan Roh Kudus 
kepada para murid (Kis 2:1-4). Ini menunjukkan ada dua perisiwa (pengalaman) yang berbeda yang harus dialami oleh para murid dengan Roh Kudus.

Kedua, orang Samaria yang Bertobat (Kis 8:14-17). Filipus memberitakan Injil di Samaria sehingga banyak orang bertobat, percaya dan dibaptis dalam nama Tuhan Yesus. Pastilah mereka telah dilahirkan baru oleh Roh Kudus ketika itu. Tapi kemudian mereka menerima Roh Kudus ketika rasul-rasul datang dari Yerusalem dan menumpangkan tangan atas mereka.

Ketiga, Rasul Paulus. Penglihatan pada jalan menuju Damsyik membuat Paulus mengaku ketuhanan Yesus (Kis 9:3-6). Itulah saat pertobatan Paulus yang tentu dikerjakan oleh Roh Kudus. Tetapi kemudian Ananias datang dan menumpangkan tangan ke atas Paulus, dia terlepas dari kebutaannya dan dipenuhkan Roh Kudus (Kis 9:17).

Keempat, murid-murid di Efesus (Kis 19:1-7). Paulus menemukan beberapa murid di Efesus yang telah menerima baptisan Yohanes. Paulus bertanya kepada mereka, apakah mereka telah menerima Roh Kudus ketika mereka percaya? Apakah makna pertanyaan Paulus ini? Seandainya semua murid menerima pengalaman Roh Kudus ini ketika mereka percaya, mengapa Paulus menanyakan hal ini kepada mereka? Pertanyaan itu menunjukkan bahwa mungkin saja seseorang menjadi percaya tanpa menerima kepenuhan Roh Kudus.

\section{Bagaimana Seseorang Dapat Menerima Baptisan Roh Kudus?}

Sesungguhnya baptisan Roh Kudus adalah karunia Tuhan. Pemberian ini adalah kedaulatan Allah kepada orang-orang percaya yang haus akan baptisan Roh Kudus yang meminta di dalam doa dengan iman (Yoh 7:37-39).

Bahasa roh ialah suatu bahasa baru yang diberikan oleh Roh Kudus kepada orang-orang yang menerima baptisan Roh Kudus, suatu bahasa yang tidak pernah mereka pelajari, suatu bahasa yang asing yang tidak dapat dimengeri oleh yang mengucapkannya atau pun yang mendengarkannya, sebab ia mengucapkan hal-hal yang rahasia yang dimengerti oleh Allah saja (I Kor 14:2). Ini nyata dari pengalaman orang Kristen mula-mula yang dicatat oleh Alkitab:

1. Pada hari Pentakosta, 120 murid penuh Roh Kudus dan berkata dalam bahasa lain (Kis 2:4). 
2. Orang-orang yang berada di rumah Kornelius menerima Roh Kudus, mereka berkat-kata dalam bahasa roh dan memuliakan Allah (Kis 10:44-48, 11:15-17).

3. Petrus dan Yohanes menumpangkan tangan ke atas orang-orang Samaria maka turunlah Roh Kudus atas mereka disertai tandatanda yang membuat Simon takjub (Kis 8:14-19).

4. Para murid di Efesus memberi diri dibaptis, dan ketika Paulus menumpangkan tangan di atas mereka maka turunlah Roh Kudus atas mereka (Kis 19:5-6).

5. Paulus penuh dengan Roh Kudus (Kis 9:17). Kita yakin dia berkata-kata dalam bahasa roh karena ucapannya kepada jemaat di Korintus dalam I Kor 14:18.

Apakah Bahasa Roh yang Asli Masih Ada Pada Masa Kini atau Sudah Berhenti Setelah Zaman Para Rasul?

I Korintus 13:8-10 menunjukkan bahwa bahasa roh, nubuat, dan karunia pengetahuan (marifat) akan lenyap. Kapan? Jika yang sempurna tiba. Apakah yang sempurna itu sudah tiba? Menurut kaum Reformed yang dipahami sebagai kesempurnaan itu adalah kanonisasi Alkitab secara lengkap 66 kitab dihimpun menjadi satu. Sedangkan kaum Pentakosta meyakini bahwa yang sempurna itu adalah kedatangan Kristus kembali, yakni saat kita akan melihat Dia dalam keadaan yang sebenarnya (I Kor 13:11-12 dan I Yoh 3:2). Jadi sampai Yesus datang kembali, bahasa roh masih tetap ada.

Perlu dibedakan manifestasi bahasa roh sebagai:

1. Glossolalia, yakni bahasa yang tidak dimengerti oleh orang yang mengucapkan atau mendengarkannya, karena tidak pernah dipelajari sebelumnya. Ia mengucapkan bahasa itu karena ilham atau dorongan Roh Kudus (I Kor 14:2).

2. Suatu bahasa asing yang ada di dunia (mis: Belanda, Spanyol, Jepang dll) yang kita ucapkan padahal belum pernah dipelajari sebelumnya. Contoh: Pada hari Pentakosta apa yang diucapkan oleh para rasul dipahami oleh orang dari berbagai bangsa dan bahasa (Kis 2:1-13). Dalam ilmu linguisik disebut dengan isilah: xenolalia. Ini juga bisa merupakan tanda untuk orang yang tidak beriman, sedangkan nubuat adalah tanda untuk orang beriman ( I Kor 14:22). 
Kadang orang bertanya: Mengapa dalam ibadah gereja Pentakosta/ Kharismatik orang berkata-kata dalam bahasa roh bersama-sama, padahal Paulus berkata bahwa dalam pertemuan jemaat maksimal hanya 3 orang yang boleh berbahasa roh, satu demi demi dan harus ada yang menafsirkannya? (I Kor 14:27-28). Di sini perlu dibedakan antara:

1. Karunia bahasa roh yang harus ditafsirkan untuk membangun jemaat (bahasa roh untuk tujuan nubuatan). Ini yang dibahas Paulus dalam I Kor 14:27-28.

2. Bahasa roh sebagai tanda awal baptisan Roh Kudus seperti yang dialami orang percaya dalam Kis 2:1-4 (120 bersama-sama) atau dalam Kis 19:6-7 (12 orang bersama-sama). Ini adalah bahasa roh untuk tujuan penyembahan. Jadi jika itu adalah bahasa roh sebagai tanda baptisan Roh Kudus yang fungsinya untuk membangun kerohanian diri (I Kor 14:4a) maka bisa dilakukan bersama-sama dalam ibadah, seperti halnya pada hari Pentakosta.

Bahasa Roh perlu digunakan terus (I Kor 14:5,18,39). Faedah bahasa Roh antara lain:

1. Tanda baptisan Roh Kudus.

2. Menolong ketika kita lemah (Rm 8:26).

3. Membangun iman (menjadikan rohani kuat) I Kor 14:4, Yud $1: 20$.

4. Membuat lebih peka secara rohani.

5. Mengucapkan bahasa rahasia (I Kor 14:2).

6. Menyucikan mulut kita.

7. Menyegarkan roh kita (Yes 28:11-12).

8. Memuji Allah (I Kor 14:15, Ef 5:19).

9. Memelihara kepenuhan Roh Kudus (Ef 5:18).

Baptisan Roh Kudus bukanlah merupakan sebuah puncak pengalaman rohani, melainkan pintu masuk ke dalam berjenis-jenis pelayanan dalam Roh yang disebut karunia-karunia roh. I Kor 12:910 mencatat 9 karunia manifestasi Roh yang bisa digolongkan menjadi:

1. Karunia Pernyataan, untuk mengucapkan kata: hikmat, pengetahuan, membedakan roh.

2. Karunia Kuasa, untuk melakukan tanda-tanda ajaib: iman, menyembuhkan, mujizat. 
3. Karunia Pengungkapan, untuk mengungkapkan hal yang tersembunyi: nubuat, bahasa roh dan menafsirkan bahasa roh.

Karunia tersebut dalam pelaksanaannya sering bekerja sama dan tak terpisahkan. Karunia-karunia roh ini bukanlah sesuatu yang wajar, dapat dipelajari, karunia alamiah, tetapi merupakan manifestasi ilahi secara supranatural. Orang yang mendapat karunia ini adalah orang yang dipenuhi oleh Roh Kudus.

Karunia Roh untuk melayani ini harus diimbangi dengan buah Roh (Gal 5:22-23). Keika Roh Kudus memenuhi hidup seseorang maka Ia bekerja keluar dengan memberikan karunia-karunia Roh, dan ke dalam dengan memunculkan buah Roh. Buah Roh bukan sifat alamiah tetapi karakter orang percaya yang dibarui karena melekat pada Kristus (Yoh 15:5). Itu meliputi:

1. Hubungan dengan Allah (Vertikal) pengalaman Kristen: kasih, sukacita, damai sejahtera.

2. Hubungan dengan sesama (horizontal) tingkah laku Kristen: kesabaran, kemurahan, kebaikan.

3. Hubungan dengan diri sendiri (internal) budi pekeri Kristen: kesetiaan, kelemahlembutan, penguasaan diri.

Karakter Kristus yang indah di dalam kita disertai karuniakarunia Roh menyebabkan pelayanan dan kesaksian kita menjadi semakin efektif.

\section{Penuh dengan Roh Kudus}

\section{Definisi Penuh Dengan Roh Kudus}

Dalam Efesus 5:18 dikatakan, "Dan janganlah kamu mabuk oleh anggur, karena anggur menimbulkan hawa nafsu, tetapi hendaklah kamu penuh dengan Roh," Dalam ayat ini Rasul Paulus menasihatkan Jemaat supaya penuh dengan Roh Kudus, bukan mabuh oleh anggur. Penuh dengan Roh Kudus dibandingkan dengan mabuk oleh anggur. Keduanya memiliki keadaan berada dalam pengaruh, control. Orang yang dikontrol anggur menimbulkan hawa nafsu, tetapi orang yang dikuasai Roh akan mengalami kuasa Roh Kudus yang besar.

Kata yang dipakai adalah pleroo yang artinya memenuhi, mengisi sampai penuh. Dalam Kamus Besar Bahasa Indonesia, kata penuh artinya 1 sudah berisi seluruhnya (tidak ada yang terluang 
lagi); 2 banyak memuat;3 banyak sekali; 4 ki tidak kurang dari jumlah yang seharusnya; 5 ki lengkap; sempurna. ${ }^{5}$

Seorang percaya yang penuh Roh Kudus berarti Roh Kudus menguasai atau mengendalikan seluruh segi kehidupan orang percaya tersebut sehingga apa yang dilakukan seperti apa yang Roh Kudus mau. Tidak ada lagi tempat untuk hal-hal kedagingan dan kepentingan pribadi.

Kata kerja yang dipakai dalam bentuk present continuous. Brian J. Bailey menjelaskan tense ini menujukkan waktu sekarang dan berkelanjutan dengan Roh Kudus. Harus ada perluasan yang terus menerus dan berkelanjutan dalam kapasitas rohani kita untuk menerima Roh Kudus lebih banyak."

Dipenuhi oleh Roh Kudus artinya adalah dikuasai, dipimpin, dibimbing, oleh Roh Kudus. Seseorang yang dipenuhi Roh Kudus, menyadari bahwa bagian yang bisa dia lakukan adalah mentaati apa yang Roh Kudus kehendaki dalam dirinya. Paulus menyebut kata dipenuhi oleh Roh, bersamaan dengan larangan mabuk oleh anggur. Karena keduanya menjelaskan dampak dari "dikuasai". Orang yang mabuk oleh anggur biasanya tidak bisa mengontrol dirinya, perkataan dan tindakannya kacau, bahkan sering menimbulkan kekacauan lebih luas terhadap sekitarnya. Orang yang mabuk oleh anggur, hidupnya dikuasai oleh anggur. Paulus meminta jemaat menjauhi kemabukan oleh anggur, karena itu hanya kebodohan yang mengacaukan (ayat 17). Sebaliknya, Paulus berkata hendaklah kamu penuh dengan Roh (ayat 18). Hendaklah kamu hidup dikuasai dan dipimpin oleh Roh Kudus. ${ }^{6}$

Menurut renungan back To Bible (RBTB), kepenuhan Roh Kudus memiliki dua pengertian yaitu temporal dan permanen.

"Kepenuhan Roh Kudus meliputi dua pengertian.Pertama, kepenuhan Roh Kudus secara temporal. Ini adalah kepenuhan Roh Kudus hanya seketika (temporal), yaitu ketika Tuhan memenuhi seseorang dengan Roh-Nya untuk tanda kehadiran-Nya. Biasanya suasana atau saat itu disertai dengan demonstrasi kekuasaan Allah. Demonstrasi kuasa Allah di sini adalah karunia-karunia Roh Kudus yang berguna untuk membangun jemaat dan tanda bagi orang yang

${ }^{5}$ Kamus Besar Bahasa Indonesia Online, https://kbbi.web.id/penuh

${ }^{6}$ Brian J. Bailey, Roh Kudus Sang Penghibur, Nafiri Gabriel, 1997, hal 114

Brian J. Bailey, Roh Kudus Sang Penghibur, Nafiri Gabriel, 1997, hal 114 
tidak mengenal Allah sehingga mereka mengakui bahwa Allah ada di tengah-tengah mereka. Karunia-karunia tersebut bisa berupa penglihatan, bahasa Roh / lidah asing dan lain sebagainya. Kisah seperti ini banyak terdapat dalam kitab kisah Rasul.

Kepenuhan ini bersifat hanya sementara waktu, biasanya kepenuhan seperti ini terjadi pada waktu dibutuhkan dalam pertemuan-pertemuan jemaat. Biasanya gereja-gereja aliran aliran tertentu sangat memburu hal ini dan mereka memandangnya sebagai keunggulan pelayanan gerejanya.

Pengertian yang kedua, kepenuhan Roh Kudus secara permanen. Kepenuhan Roh Kudus secara permanen ini dialami atau terjadi ketika seseorang "berjalan bersama dengan Tuhan" dalam kurun waktu yang panjang sehingga dapat mengerti kehendak Tuhan dan mampu untuk melakukannya.

Hal ini dapat dicapai melalui perjuangan berat, yaitu belajar kebenaran Firman Tuhan, mengerti kehendak Tuhan, mematikan kedagingan, merubah tujuan hidup dan berbagai proses kehidupan melalui segala pengalaman hidup. Kepenuhan Roh Kudus secara permanen tidak harus ditandai dengan karunia, tetapi pasti ditandai dengan buah Roh"7

Beberapa peristiwa yang menceritakan penuh Roh Kudus secara temporer antara lain: Pertama, pada hari Pentakosta (Kisah Para Rasul 2). Murid-murid yang sedang berkumpul di sebuah ruang atas di Yerusalem menantikan janji Yesus tentang turunnya Roh Kudus. Tiba-tiba tampak oleh mereka lidah-lidah seperti nyala api yang bertebaran dan hinggap pada mereka. Maka mereka penuh dengan Roh Kudus lalu mulai berkata-kata dalam bahasa lain seperti yang diberikan oleh Roh Kudus. Ada yang berbahasa Partia, Media, Elam, Kapadokia, dan sebagainya. Petrus dengan berani bangkit berdiri dan berkothbah kepada orang-orang yang berkumpul di tempat itu.

Kedua, Petrus menyembuhkan orang lumpuh di Pintu Gerbang Bait Allah (Kis. 3:1-10). Dikatakan pada saat itu Petrus penuh dengan Roh Kudus, sehingga ada kuasa dalam perkataannya.

\footnotetext{
${ }^{7}$ Rita Setyoningtyas, Dipenuhi Roh Kudus (Efesus 5:18),http://gkwi.org/multimedia-archive/dipenuhi-roh-kudus-efesus-5-14-21/.
} 
Ketiga, Ananias mendoakan Saulus dan menumpangkan tangannya sehingga Saulus yang buta bisa melihat kembali (Kisah Para Rasul 9). Dalam perjalanan ke Damsyik untuk menganiaya umat Tuhan, Saulus berjumpa dengan Yesus dalam cahaya yang menyilaukan dan matanya menjadi Buta. Ananias diutus Tuhan untuk mendoakan dan menumpangkan tangannya sehingga Saulus sembuh dan berbalik menjadi pengikut Tuhan yang militan. Masih banyak lagi cerita yang lain dalam kehidupan jemaat mula-mula dan pelayanan para rasul.

Pengertian penuh Roh Kudus dalam Efesus 5:18 menekankan tindakan secara permanen dimana setiap orang percaya berada dalam kendali atau kontrol Roh Kudus dalam setiap segi hidupnya dan terus memperluas karya Roh Kudus yang membawa kepada pertumbuhan rohani yang progresif. Orang percaya menyerahkan hidupnya kepada pimpinan Roh Kudus.

\section{Dampak Dari Penuh Dengan Roh Kudus}

Dampak yang pertama adalah perubahan karakter yang nyata dan mengalami Pertumbuhan Rohani. Rasul Petrus sebelum mengalami kepenuhan Roh Kudus adalah seorang yang lemah dan mudah terombang-ambing. Petrus pribadi yang begitu bersemangat tetapi juga mudah patah semangatnya bahkan sampai menyangkal Yesus tiga kali sebelum ayam berkokok. Setelah mengalami kepenuhan Roh Kudus ia menjadi seorang yang berani. Dia dengan lantang berani berbicara kepada orang-orang yang hadir saat hari Pentakosta tersebut (Kisah Para Rasul 4:8). Dia menjadi orang yang benar-benar komitmen dengan Tuhan sampai akhir hidupnya dengan penuh keberanian melayani Tuhan.

Hal yang sama juga dialami oleh murid-murid lain yang dengan berani memberitakan firman Allah (Kisah Para Rasul 4:31). Perubahan yang nyata juga dialami oleh Rasul Paulus, seorang penganiaya jemaat menjadi pengikut Kristus yang militant bahkan mati untuk Kristus.

Dampak yang kedua dari orang yang ada di dalam kendali Roh Kudus adalah akan mengasilkan buah Roh (Galatia 5:22-23). "Tetapi buah Roh ialah: kasih, sukacita, damai sejahtera, kesabaran, kemurahan, kebaikan, kesetiaan, kelemahlembutan, penguasaan diri. Tidak ada hukum yang menentang hal-hal itu." Roh yang ada dalam 
hidup orang percaya akan memberikan kuasa dan kemampuan kepadanya untuk meninggalkan kedagingan dan hidup dalam pimpinan Roh Kudus. Semakin Roh Kudus penuh dalam diri orang percaya, semakin kecil tempat bagi keinginan daging. Jadi keinginan daging bisa dikalahkan apabila orang percaya semakin mengijinkan Roh Kudus memegang kendali atas hidupnya. Galatia 5:16, "Maksudku ialah: hiduplah oleh Roh, maka kamu tidak akan menuruti keinginan daging." Dengan demikian kehidupan rohani akan bertumbuh dan buah-buah Roh semakin matang.

Dampak ketiga dari orang yang ada dalam kendali Roh Kudus adalah akan dipimpin pada seluruh kebenaran, sehingga memampukan manusia untuk hidup benar di hadapan Allah. Ketidakmampuan digantikan dengan kuasa Allah sehingga mampu melakukan kebenaran firman Allah. Dari dalam kehidupan yang dipenuhi oleh Roh mengalirlah kebenaran tentang kehidupan yang dipimpin oleh Roh. Mereka yang terus menerus mencari Tuhan untuk memperoleh Roh-Nya lebih banyak lagi layak untuk mengalami kehidupan yang dipimpin Roh. Pimpinan Roh ini akan membuat orang percaya mampu menggenapi rencana Allah dalam hidupnya. ${ }^{8}$

Tuhan Yesus berkata kepada Petrus di dalam Matius 16:18, "Dan Aku pun berkata kepadamu: Engkau adalah Petrus dan di atas batu karang ini Aku akan mendirikan jemaat-Ku dan alam maut tidak akan menguasainya." Yesus menubuatkan bahwa Petrus akan menjadi pondasi bagi pembangunan gereja Tuhan.

Ketika Yesus menubuatkan hal ini, kondisi Petrus masih tidak stabil, mudah goyah.Setelah Roh Kudus turun, saat Ro Kudus memenuhi Petrus dengan kuasa-Nya, dia bangkit dan memulai kegerakan gereja mula-mula. Tuhan benar-benar memakai Petrus untuk membangun gereja Tuhan, sebagai orang yang kuat kokoh seperti batu karang yang tidak tergoyahkan.

Saulus, seorang penganiaya jemaat Tuhan pada awalnya, tetapi setelah dipenuhi Roh Kudus ia dipanggil untuk menjadi pemberita Injil terutama di kalangan bangsa-bangsa di luar Yahudi. Roh Kudus memberi kuasa kepadanya untuk melakukan tugas

${ }^{8}$ Brian J. Bailey, Roh Kudus Sang Penghibur, Nafiri Gabriel, Jakarta, 1997, 
panggilan tersebut sehingga bangsa-bangsa bukan Yahudi mengenal berita Injil dan mengalami keselamatan.

Tuhan memakai jemaat-Nya untuk melakukan tugas dan panggilannya dalam pekerjaan Tuhan dimanapun Tuhan tempatkan baik dalam keluarga, dunia kerja maupun pelayanan.

Dampak keempat dari orang yang ada di dalam kendali Roh Kudus adalah akan memiliki kuasa untuk memberitakan Injil. Kisah Para Rasul 1:8 mengatakan, "Tetapi kamu akan menerima kuasa, kalau Roh Kudus turun ke atas kamu, dan kamu akan menjadi saksi$\mathrm{Ku}$ di Yerusalem dan di seluruh Yudea dan Samaria dan sampai ke ujung bumi."

Menjadi saksi yang dimaksud adalah menjadi saksi akan kuasa dan karya penyelamatan oleh Yesus Kristus dan memberitakan kepada orang-orang di sekeliling bahkan sampai bangsa-bangsa lain. Dengan kuasa Roh Kudus orang percaya dimampukan untuk menjadi saksi karena Roh Kuduslah yang memimpin orang kepada kebenaran. Kesaksian akan punya kuasa kalau Roh Kudus ada di dalamnya. Roh Kudus juga memberitan tanda-tanda dan mujizat tertentu supaya pemberitaan Injil efektif. Seperti kesembuhan ilahi, pengusiran setan, pelepasan, dan lain lain.

\section{Bagaimana agar Hidup Orang Percaya Penuh Roh Kudus?}

a. Taat dan menanti-nantikan

Sebelum naik ke sorga, Tuhan memerintahkan murid-murid untuk tinggal di Yerusalem menantikan janji Bapa. Kisah Para Rasul 1:4, "Pada suatu hari ketika Ia makan bersama-sama dengan mereka, Ia melarang mereka meninggalkan Yerusalem, dan menyuruh mereka tinggal di situ menantikan janji Bapa, yang -- demikian kata-Nya -- "

Para murid mentaati perintah tersebut dan tetap tinggal di Yerusalem menantikan janji Bapa tentang Roh Kudus yang akan dicurahkan ke atas mereka. Ketaatan pada perintah dan firman Allah akan membuat seseorang mengalami pimpinan-Nya. Sikap menantinantikan menggambarkan suatu kerinduan karena keyakinan janji Yesus pasti digenapi.

b. Berkata-kata kepada diri sendiri dalam Mazmur, kidung pujian dan nyanyian rohani (Efesus 5:19) 
Kepada diri sendiri kita hendaknya mengatakan hal-hal yang membangun berupa Mazmur, pujian dan nyian rohani supaya Roh Kudus menguasai seluruh hidup kita. Kita harus menaklukkan jiwa kepada kendali Roh Kudus.

Raja Daud dalam Mazmur 43 berbicara kepada jiwanya yang patah semangat dan memerintahkannya untuk berharap di dalam Allah. Ia menaklukkan jiwa dan emosinya yang sedang menguasainya, Kita tidak perlu dikalahkan oleh jiwa dan membiarkan emosi-emosi kita mengusai kita. Ini hanya akan memimpin kepada kekacauan dan malapetaka. Kita dapat mengalahkan sifat kita yang dikontrol jiwa dengan jalan dipenuhi Roh Kudus secara terus menerus. Kunci untuk menjadi spiritual untuk menjadi spiritual adalah mengambil otorita atas emosi-emosi kita dengan berbicara kepada jiwa kita dan membiarkan kehidupan Roh mengalir melalui kita. ${ }^{9}$

c. Hidup dalam persekutuan dengan orang percaya

Ketika menantikan janji Bapa, para murid selalu berkumpul bersama dan berdoa. Mereka percaya apa yang dijanjikan Yesus akan segera digenapi.

\section{d. Mengalami Baptisan Roh Kudus}

Baptisan Roh Kudus merupakan syarat mutlak supaya mengalami kepenuhan Roh Kudus. Tanpa masuknya Roh Kudus dalam hidup seseorang, tidak mungkin akan mengalami kepenuhan Roh Kudus.

\section{e. Hidup dalam pimpinan Roh Kudus}

Seorang yang dipimpin Roh Kudus menyerahkan seluruh aspek hidupnya kepada pimpinan Roh Kudus. Aliran-aliran Roh akan terus mengalir memenuhi hidupnya sehingga akan mengalami puas dalam Roh (Yohanes 4:14). "tetapi barang siapa minum air yang akan Kuberikan kepadanya, ia tidak akan haus untuk selama-lamanya. Sebaliknya air yang akan Kuberikan kepadanya, akan menjadi mata air di dalam dirinya, yang terus-menerus memancar sampai kepada hidup yang kekal."

${ }^{9}$ Brian J. Bailey, Roh Kudus Sang Penghibur, Nafiri Gabriel, Jakarta, 1997, 


\section{Penghambat Hidup Penuh Roh Kudus}

Penghalang utama tidak dipenuhi Roh Kudus adalah dosa dan kedagingan. Orang yang hidup dalam dosa dan kedagingan, dikendalikan oleh dosa dan kedagingan, penuh dengan kedagingan. Rupa-rupa kedagingan dijelaskan dalam Galatia 5:19-21, "Perbuatan daging telah nyata, yaitu: percabulan, kecemaran, hawa nafsu, penyembahan berhala, sihir, perseteruan, perselisihan, iri hati, amarah, kepentingan diri sendiri, percideraan, roh pemecah,kedengkian, kemabukan, pesta pora dan sebagainya. Terhadap semuanya itu kuperingatkan kamu -- seperti yang telah kubuat dahulu -- bahwa barangsiapa melakukan hal-hal yang demikian, ia tidak akan mendapat bagian dalam Kerajaan Allah.”

Keinginan daging bertentangan dengan keinginan Roh (Galatia 5:17), "Sebab keinginan daging berlawanan dengan keinginan Roh dan keinginan Roh berlawanan dengan keinginan daging - karena keduanya bertentangan — sehingga kamu setiap kali tidak melakukan apa yang kamu kehendaki.”

\section{Kesimpulan}

Baptisan Roh Kudus dilakukan oleh Yesus Kristus, karena Kristus mengutus Roh Kudus sebagai penolong bagi orang percaya. Ini adalah sebuah pengalaman kristiani yang mula pertama sekali, yang memasukkan orang percaya ke dalam persekutuan dengan Kristus. Baptisan Roh yang diberikan sekali untuk selamanya dan tidak dapat hilang. Di dalam baptisan Roh, Kristuslah yang bekerja aktif, sarananya adalah Roh, hasilnya adalah mendapatkan kuasa.

Baptisan Roh Kudus adalah karunia Tuhan. Pemberian ini adalah kedaulatan Allah kepada orang-orang percaya yang haus akan baptisan Roh Kudus yang meminta di dalam doa dengan iman. Bahasa Roh ialah suatu bahasa baru yang diberikan oleh Roh Kudus kepada orang-orang yang menerima baptisan Roh Kudus, suatu bahasa yang tidak pernah mereka pelajari, suatu bahasa yang asing yang tidak dapat dimengerti oleh yang mengucapkannya ataupun yang mendengarkannya, sebab ia mengucapkan hal-hal yang rahasia yang dimengerti oleh Allah saja. Baptisan Roh Kudus merupakan pintu masuk ke dalam berjenis-jenis pelayanan dalam Roh yang disebut karunia-karunia roh. 
Dipenuhi oleh Roh Kudus artinya adalah dikuasai, dipimpin, dibimbing, oleh Roh Kudus. Seseorang yang dipenuhi Roh Kudus, menyadari bahwa bagian yang bisa dia lakukan adalah mentaati apa yang Roh Kudus kehendaki dalam dirinya. Seorang percaya yang penuh Roh Kudus berarti Roh Kudus menguasai atau mengendalikan seluruh segi kehidupan orang percaya tersebut sehingga apa yang dilakukan seperti apa yang Roh Kudus mau. Tidak ada lagi tempat untuk hal-hal kedagingan dan kepentingan pribadi.

Dampak dari kepenuhan Roh Kudus adalah perubahan karakter dan pertumbuhan rohani, hidup dipimpin Roh Kudus kepada kehendak Tuhan dalam panggilan khususnya, dan memiliki kuasa untuk memberitakan Injil.

Sedangkan hal yang diperlukan supaya mengalami kepenuhan Roh adalah taat dan menanti-nantikan; berkata-kata kepada diri sendiri dalam Mazmur, kidung pujian dan nyanyian rohani; hidup dalam persekutuan dengan orang percaya; mengalami baptisan Roh Kudus; dan hidup dalam pimpinan Roh Kudus.

Adapun penghambat seseorang penuh Roh adalah hidup dalam dosa dan kedagingan. Hal ini karena keinginan daging bertentangan dengan keinginan Roh.

\section{Kepustkaan}

Alkitab.2010. Jakarta: Lembaga Alkitab Indonesia. Jakarta

Brian J. Bailey. 1997. Roh Kudus Sang Penghibur, Buah Roh \& Hidup Yang Dipimpin Roh. Jakarta: Nafiri Gabriel

Brian J. Bailey.1997.Roh Kudus Sang Penghibur, Baptisan dan Karunia Roh. Jakarta: Nafiri Gabriel

.1986. Tafsiran Alkitab Masa Kini 3 Matius - Wahyu. Jakarta: BPK Gunung Mulia

Bonke, Reinhard. Holy Spirit Revelation \& Revolution, ANDI Ofset, Yogyakarta, 2007

Bruner, A Theology of the Holy Spirit, Trinity Foundation 2001

Bevere, John.2015.Roh Kudus Sebuah Pengantar. (t.p)

Simpson. A.B. 1993. Mengikuti Pimpinan Roh. Bandung: Kalam Hidup

Stott, John R.W.1999. Baptisan dan Kepenuhan: Peranan dan Karya Roh Kudus Masa kini. Jakarta: Yayasan Bina Kasih/OMF 